Volume 42

Number 4 Vol. 42, No. 4-5

7-1998

\title{
The Society of St. Vincent de Paul
}

\author{
César Nunes Viana
}

Follow this and additional works at: https://via.library.depaul.edu/vincentiana

Part of the Catholic Studies Commons, Comparative Methodologies and Theories Commons, History of Christianity Commons, Liturgy and Worship Commons, and the Religious Thought, Theology and Philosophy of Religion Commons

\section{Recommended Citation}

Nunes Viana, César (1998) "The Society of St. Vincent de Paul," Vincentiana: Vol. 42: No. 4, Article 21. Available at: https://via.library.depaul.edu/vincentiana/vol42/iss4/21

This Article is brought to you for free and open access by the Vincentian Journals and Publications at Digital Commons@DePaul. It has been accepted for inclusion in Vincentiana by an authorized editor of Digital Commons@DePaul. For more information, please contact digitalservices@depaul.edu. 


\title{
The Society of St. Vincent De Paul
}

\author{
by César Nunes Viana \\ International President of the \\ Society of St. Vincent de Paul
}

The Society of St. Vincent de Paul is a lay society always faithful to the Church and to the spirit of St. Vincent de Paul. It was founded by Frederick Ozanam in 1833. At that time the dramatic consequences of the French Revolution were being felt. Sickness and poverty created victims on all sides. Under the inspiration of its founder, Ozanam, who had six companions, the first Conference was born, and that became the basis of all Vincentian work. Its objective was to reflect on the social situation and, at the same time, to promote works of concrete help to all of those who suffered sickness or hunger. This was truly a prophetic inspiration, proven by its rapid spread throughout France and many other countries.

Today the Society of St. Vincent de Paul functions in over 135 countries, with over 900,000 members distributed in 50,000 conferences. The fundamental lines of the Society of St. Vincent de Paul are found in the spirituality of the entire Vincentian Family and, as with all its work, are inspired by the Gospel, faithful to the ideals of St. Vincent de Paul and their interpretation by Ozanam.

The works which the members carry out always begin with a person-to-person dialogue. Their visits to the poor are carried out in a spirit of poverty and mutual acceptance. The Society of St. Vincent de Paul is alert to see remedies for all types of poverty, material or spiritual. This attitude of dialogue must always characterize their visits to the poor, and also serves to create mutual and open dialogue among the members themselves.

The conferences are organized on a parish basis, though the cells may be set up in schools and universities, and even in some commercial enterprises. When a conference prepares its visits, the members must bring a certain spirituality, a broad and specific formation, as well as specific information about the difficulties encountered, in order to seek adequate solutions in a family spirit.

The final objective is to find the efficacious and opportune solution in solving situations of material or spiritual poverty without forgetting the immediate emergency which they are taking care of. We try to develop the relationships of the Society of St. Vincent de Paul with other branches of the Vincentian Family, not only insofar as there is a fraternal and cordial attitude among the members, but also everything which concerns information, communication of significant experience and carrying out of projects in collaboration. There are hopes and aspirations to better the situations and not to let them die. These characteristics can be realized in different ways. It is important also that we all have days of prayer and reflection in common, especially on 
the feast of St. Vincent de Paul (September 27), and it is hoped that this day could be celebrated by all the branches of the Vincent Family present in any one place.

After the beatification of Frederick Ozanam we Vincentians would like to celebrate September 9 (feast of Ozanam) and promote a meeting for all members during the weekend of April 23, 1999. At that time we can look into the possibility of organizing our members who live in countries with greater material and spiritual needs.

With reference to the third millennium and inspired by Frederick Ozanam, aware that we are living in revolutionary times, maybe even more dramatic than the times of Ozanam, we are going to organize a plenary Assembly in Fatima after Easter in 1999. There we will study various problems which have come up in our modern era. In the time of Ozanam, the Industrial Revolution substituted machinery in the place of man, and today modern technology, computers, substitute even for intellectual tasks.

Therefore it is necessary that we exercise imagination to permit greater social justice in greater fidelity to new areas of development in the world. There are just too many problems, such as strikes, lack of housing, systematic destruction of the family, new diseases, and new forms of poverty, like AIDS, cancer, the exploitation of poor peoples through drug trafficking by the richer nations within the framework of liberal neo-capitalism.

In all these things, the Vincentians have a fundamental job: that Christian charity give sense to our lives, so that we can collaborate, one with another, making Christian brotherhood every more alive and present. 